\title{
Kinetic Modeling of Adsorption of Indigo Carmine (5, 5'- Disulfonic Indigotin) on Peat
}

\author{
Maria Fernanda G.Vidal ${ }^{1}$ and Patricia Antonio de Menezes Freitas ${ }^{1, *}$ \\ ${ }^{1}$ Escola de Engenharia Mauá, Instituto Mauá de Tecnologia \\ Praça Mauá 1, 09580-900, SP, São Caetano do Sul, SP, Brazil \\ pantonio@maua.br
}

\begin{abstract}
The kinetic of Indigo Carmine (5,5'- disulfonic indigotin, 5,5'-DI) adsorption on fibrous peat (FP) and decomposed peat (DP), have been investigated at different temperatures $(283,298,313) \mathrm{K}$ at $\mathrm{pH}$ 2. The effect of particle size was studied considering the variation of grain size of each peat (2000-850, 850-600 and < 600) $\mathrm{nm}$. The fibrous peat shows higher adsorption capacity than the decomposed peat, while under the same work conditions. The kinetics of adsorption of 5,5'-DI is discussed using three kinetic models, the first-order Lagergren model, the pseudo-second-order model, and the intraparticle diffusion model. The adsorption of 5, 5'-DI onto peat proceeds according to the pseudo second-order model and the correlation coefficients were very close to 1 . At 283, 298 and $313 \mathrm{~K}$ the maximum sorption, $q_{\text {max } \text { calc }}$, for the initial concentration $\left(C_{o}=4.05 \times 10^{-5}\right.$ $\left.\mathrm{mol} \mathrm{L}^{-1}\right)$ of 5,5'-DI were $q_{\text {max,calc }}$ is $\left(5.57,7.92\right.$ e 8.29) $\times 10^{-4} \mathrm{~g} \mathrm{~g}^{-1}$ for fibrous peat and $\left(5.29,6.74\right.$ e 5.83) $\times 10^{-4}$ $g g^{-1}$ for decomposed peat. The intraparticle diffusion of 5,5'-DI molecules within the peat particles was identified as the rate-limiting step.
\end{abstract}

Keywords: Adsorption, peat, kinetic modeling, indigo carmine, spectrophotometry.

\section{INTRODUCTION}

A number of materials have been used for solid-liquid extraction [1-3], such as polyurethane foam [4], polymeric resins [5-7], modified silica gel [8-10] and active carbon [11]. Some biological materials and products derived from industrial and agricultural activities have been also used as adsorbents for metals and other substances, mainly aiming remediation of contaminated water $[12,13]$. Rice [14], grape husks [15], sugarcane bagasse [16], bamboo charcoal [17] and microorganisms [18] were used as alternative solid-phases in the development of analytical methods for dye determination. Taking into account these characteristics, peat stands for a natural adsorbent for water remediation and analytical applications. Peat is an organic sediment formed from the partial decomposition of vegetable material in an environment moist, acid and low oxygenation [20-22]. Peat in situ generally contains $90 \%$ or more of water and when collected and air-dried to this level approaches $40 \%$ [23]. With regard to their appearance, peat presents a variable coloration between dark brown and black, soft consistency when wet and tenacious when dry [24]. From the point of physicochemical view, is a porous, highly polar, with high adsorption capacity for transition metals and polar organic molecule, Figure 1 [25].

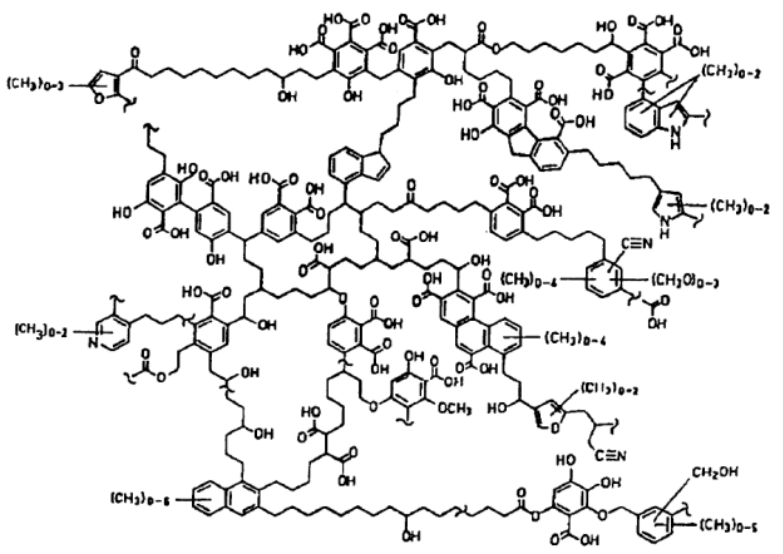

Figure1. Molecular structure of humic acid $\left(\mathrm{C}_{187} \mathrm{H}_{186} \mathrm{O}_{89} \mathrm{~N}_{9} \mathrm{~S}\right)$ 
Peat is constituted by lignin, cellulose and humicsubstances (HS) [27], thus containing functional groups like carboxylic acids and phenolic or alcoholic hydroxyls benefiting the adsorption of organic molecules and complexation of metallic ions [28]. It is an organic sediment formed by partial decomposition of vegetal matter in acid and humid media, containing low-oxygen amounts. In the last thirty years, the peat has been much studied, primarily in Canada, the US and Europe, as alternative technology of using a natural adsorber [29-31]. Low cost, applied to the treatment of water and effluents contaminated by heavy metals and other toxics substances. In Brazil, this material has its application directed to agriculture or as combustible material, given its high content of carbon,Table 1.

Table1. Brazilian regions with higher amounts of peat [30]

\begin{tabular}{cc}
\hline Brazilian regions & Peat amount in tons (billion) \\
\hline Amazon & 6 \\
South & 500 \\
Northest & 42 \\
\hline
\end{tabular}

However, few studies have been published concerning the use of national peat applied to the treatment contaminated water and wastewater $[31,32]$. This peat can be used in the preparation of composites such as bioplastics, natural adsorbent and as a source of raw materials for several processes [33]. It represents an alternative low-cost (bio)adsorbent and may be used for the removal of pollutants (metal ions, dyes and other natural and inorganic substances) present in wastewater. The retention capacity of several metallic ions in aqueous solution has been previously reported using peat as the adsorbent [34]. This study aims to use peat as a (bio)adsorbent for retention of the organic compound 5,5'-disulfonic indigotin (C.I. 73015), [35-40]. Three simplified kinetic models including pseudo-first-and -second-order [41-43] equations and the intraparticle diffusion [44,45] were used to describe the adsorption processes.

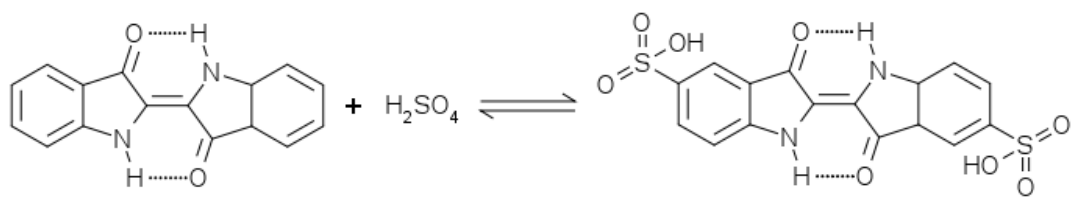

Figure2. Reaction of indigo carmine (5,5'- disulfonic indigotin) [46]

\section{EXPERIMENTAL}

\subsection{Reagents and Solutions}

All reagents and solvents used were of analytical grade. Distilled deionized water (Milli-Q) was used to prepare solutions. Indigo blue dye ((3H-indole-3-one2-(1,3-dihydro-3-oxo-2H-indol-2ylidene)-1,2dihydro) is known in literature as CI Vat Blue or D\&C no.6 and is used to dye natural and synthetic fibers [47-50]. It is a blue crystalline solid with the molecular formula $\mathrm{C}_{16} \mathrm{H}_{10} \mathrm{~N}_{2} \mathrm{O}_{2}\left(262.27 \mathrm{~g} \mathrm{~mol}^{-1}\right)$, CAS Number 482-89-3 and a melting point between (573 and 576) $\mathrm{K}$. To prepare 5,5'-disulfonic indigotin solution $\left(\mathrm{C}_{16} \mathrm{H}_{8} \mathrm{~N}_{2} \mathrm{O}_{8} \mathrm{~S}_{2}\right), 466.36 \mathrm{~g} \mathrm{~mol}^{-1}, 1.05 \mathrm{~g}$ of the Indigo blue dye (Sigma Aldrich) was added to $35 \mathrm{~mL}$ of concentrated $\mathrm{H}_{2} \mathrm{SO}_{4}$ while stirring. The sulphonated species are obtained according to the chemical reaction (Fig.2). The temperature was kept at $353 \mathrm{~K}$ and after cooling, the solution was diluted to $1000 \mathrm{~mL}$ with deionized water [35].

\subsection{Apparatus}

The UV-Vis spectra were measured on a Shimadzu Model UV-2600 spectrophotometer using 1.00$\mathrm{cm}$ quartz cells. All cuvettes, glass and plastic vessels were washed with a $10 \%(\mathrm{v} / \mathrm{v}) \mathrm{HNO}_{3}$ aqueous solution followed by distilled and deionized water to remove trace of contaminants. The $\mathrm{pH}$ measurements were performed with a Metrohm $\mathrm{pH}$-meter Model 827 with a combined glass electrode with the $\mathrm{Ag} / \mathrm{AgCl}$ reference electrode filled with $3 \mathrm{~mol} \mathrm{~L}^{-1} \mathrm{NaCl}$ solution. Centrifugation of the mixtures was carried out in a FANEM 206-R centrifuge. Agitation of the mixtures was performed on an Incubator Shaker Model AL-222-CF American Lab with controlled velocity and temperature (283, 298 and 313) K.

\subsection{Biosorbent Material Preparation}

The physico-chemical point of view, peat may be defined as a porous and highly and polar material, with high adsorption capacity and exchange cations [34]. The characteristics are directly influenced 
by their age, by climate region where it formed the bog and mainly by the type of plant that originated (grasses, trees, mosses and other bog plants) [35]. Two types of peat from Santa Catarina, Brazil, were used being a decomposed type, ie it presents some degree of humidification and another of the fibrous type, with minimal or no degree of decomposition, Table 2. The fibrous and decomposed peats were washed with deionized water and after it was dried at $313 \mathrm{~K}$ for 24 hours. It was adopted to work with different granulometries: (850 to 2000) $\mathrm{mm}$, (850 to 600) $\mathrm{mm}$ and less than $600 \mathrm{~mm}$.

Table2. Physicochemical properties of fibrous peat and decomposed peat [27, 28]

\begin{tabular}{ccc}
\hline Physicochemical Property & Fibrous peat (FP) & Decomposed Peat (DP) \\
\hline Colour & light brown & dark brown \\
$\mathrm{pH}$ & 2.18 & 3.98 \\
Moisture content & 56,30 & 67.78 \\
Ash content & 19,00 & 11.8 \\
\hline
\end{tabular}

\subsection{Adsorption Experiments}

From the stock solution in an acid medium Indigo Blue $\left(3.82 \times 10^{-3} \mathrm{~mol} \mathrm{~L}^{-1}\right)$ were prepared $10.0 \mathrm{ml}$ of solutions of different concentrations $(0.49,0.99,2.00,2.99,4.00$ and 4.76$) \times 10^{-5} \mathrm{~mol} \mathrm{~L}^{-1}$ at $\mathrm{pH} 2$. Absorption spectra were recorded with maximum at 609 and $612 \mathrm{~nm}$ using a Shimadzu UV-2600 spectrophotometer quartz cuvette and optical path $1.00 \mathrm{~cm}$. The analytical dye curves were constructed with the wavelengths chosen. The adsorption kinetics were investigated using the solution depletion method [35]. For kinetic studies, the solutions (samples and blanks) were prepared in 10.0 $\mathrm{mL}$ volumetric polyethylene flasks with screw caps. In stoppered plastic tubes, $0.1 \mathrm{~g}$ samples of peat were kept in contact with $10.0 \mathrm{~mL}$ of 5,5'-DI aqueous solutions $(2.00,2.99$ and 4.00$) \times 10^{-5} \mathrm{~mol} \mathrm{~L}^{-1}$ at $\mathrm{pH}$ 2. The system was kept under constant orbital stirring of $150 \mathrm{rpm}$ (American lab, Model LA-222 SC) and were shaken for specific periods of time at different temperatures $(283,298$ and 313) $\mathrm{K}$. Different contact times $(5,10,15,20,30,40,60$ and 120) minutes were studied. The supernatants were separated by centrifuging (Fanem ${ }^{\circledR}$, Model $208 \mathrm{~N}$ ) the mixtures and the concentration of 5,5'-DI was calculated by molecular absorption measurements at 609 and $612 \mathrm{~nm}(\mathrm{pH} 2)$, with a 1-cm optical path cell. The adsorbed amount of 5,5'-DI at equilibrium was calculated by the difference (attenuation) in the absorbance of the aliquots drawn before and after shaking. The blank solution was prepared in the same way, but without 5,5'-DI solution.

\section{RESUlts AND DiscusSiONS}

\subsection{Spectral Characteristics and Analytical Curve of 5,5'-Di}

The maximum absorbance wavelength was determined from the 5, 5'-disulfonic indigotin (5, 5'-DI) spectrum, 609 and $612 \mathrm{~nm}$, Fig. 3. The analytical curve for 5, 5'-DI aqueous solutions in the concentration range of $4.90 \times 10^{-6}$ to $4.76 \times 10^{-5} \mathrm{~mol} \mathrm{~L}^{-1}$ at $\mathrm{pH} 2$ were obtained and the respective parameters were calculated using a least-squares method. The correlation coefficients, $r^{2}=0.9970$ $(609 \mathrm{~nm})$ and $0.9984(612 \mathrm{~nm})$, reveals an excellent linear fit to the experimental data. The linear fit equations can be written as eq.(1) and eq.(2):

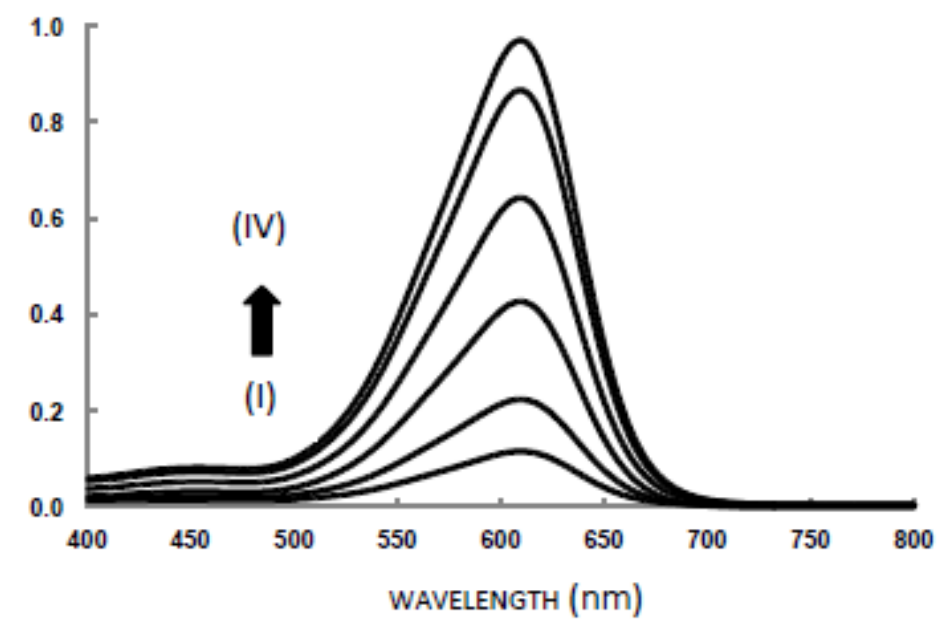

Figure3. Spectrum of indigo carmine (5, ' '- disulfonic indigotin) at pH 2, [5, 5'-DI] = (I) $0.49 \times 10^{-5}$, (II) $0.99 \times$ $10^{-5}$, (III) $2.00 \times 10^{-5}$, (IV) $2.99 \times 10^{-5}$, (V) $4.00 \times 10^{-5} e(\mathrm{VI}) 4.76 \times 10^{-5}\left(\mathrm{~mol} \mathrm{~L} \mathrm{~L}^{-1}\right)$. 


$$
\begin{aligned}
& \mathrm{A}^{609 \mathrm{~nm}}=(2.05 \pm 0.01) \times 10^{4} \times \mathrm{C}_{5,5-\mathrm{DI}}+(0.0200 \pm 0.0001) \\
& \mathrm{A}^{612 \mathrm{~nm}}=(2.01 \pm 0.02) \times 10^{4} \times \mathrm{C}_{5,5-\mathrm{DI}}+(0.0222 \pm 0.0002)
\end{aligned}
$$

\subsection{Effect of Contact Time and Particle Size}

Several experiments were conducted to assess the necessary time to obtain the maximum adsorption of 5,5'-DI onto peats. The variation of grain size of peats (2000-850, 850-600 and less than 600) $\mathrm{mm}$ was studied in order to determine the influence of the adsorption of the 5,5'-DI at pH 2 and $298 \mathrm{~K}$. Considering the initial concentration of the dye solution $4.00 \times 10^{-5} \mathrm{~mol} \mathrm{~L} \mathrm{~L}^{-1}$, FP/5,5'-DI and DP/5,5'DI systems were placed at different contact times $(5,10,15,20,30,40,60$ and 120) minutes at $298 \mathrm{~K}$. Tables 3 and 4 show the adsorbed mass of adsorbate values per gram of adsorbents as a function of the particle size of the solid phase, for contact times $(30,60,120)$ minutes at wavelengths of 609 and $612 \mathrm{~nm}$, respectively.

Table3. Mass-time profiles $\left[q t=\left(m_{5,5-D I} / m_{\text {peat }}\right)\right.$ vs. $\left.t\right]$ for adsorption of initial concentration $4.00 \times 10^{-5} \mathrm{~mol} \mathrm{~L}^{-1}$ onto fibrous peat (FP) and decomposed peat (DP) at $298 \mathrm{~K}, 609 \mathrm{~nm}$ and $298 \mathrm{~K}$.

\begin{tabular}{c|cc|cc|cc}
\hline \multicolumn{7}{c}{$\left(m_{5,5^{\prime}-\mathrm{DI}} / \mathrm{m}_{\text {peat }}\right) \times 10^{4}\left(\mathrm{~g} \mathrm{~g}^{-1}\right)$} \\
\hline Granulometry $(\mathrm{mm})$ & FP & DP & FP & DP & FP & DP \\
\hline $2000-850$ & $1.08 \pm 0.01$ & $1.82 \pm 0.01$ & $1.89 \pm 0.02$ & $2.16 \pm 0.01$ & $3.19 \pm 0,03$ & $2.82 \pm 0,02$ \\
\hline $850-600$ & $2.62 \pm 0.02$ & $2.50 \pm 0.01$ & $3.59 \pm 0.03$ & $3.20 \pm 0.01$ & $4.95 \pm 0,01$ & $3.90 \pm 0.01$ \\
\hline less than 600 & $3.54 \pm 0.01$ & $4.91 \pm 0.01$ & $6.95 \pm 0.02$ & $4.79 \pm 0.01$ & $7.09 \pm 0,01$ & $5.76 \pm 0.02$ \\
\hline Contact time (min) & \multicolumn{3}{c|}{60} & 120 \\
\hline
\end{tabular}

Table4. Mass-time profiles $\left[q t=\left(m_{5,5^{\prime}-D I} / m_{\text {peat }} v\right.\right.$ s. $\left.t\right]$ for adsorption of initial concentration $4.00 \times 10^{-5} \mathrm{~mol} \mathrm{~L}^{-1}$ onto fibrous peat (FP) and decomposed peat (DP) at $298 \mathrm{~K}, 612 \mathrm{~nm}$ and $298 \mathrm{~K}$.

\begin{tabular}{c|cc|cc|cc}
\hline \multicolumn{7}{c}{$\left(m_{5,5^{\prime}-D I} / m_{\text {peat }}\right) \times 10^{4}\left(\mathrm{~g} \mathrm{~g}^{-1}\right)$} \\
\hline Granulometry $(\mathrm{mm})$ & FP & DP & FP & DP & FP & DP \\
\hline $2000-850$ & $1.10 \pm 0.03$ & $1.83 \pm 0.02$ & $1.90 \pm 0.01$ & $2.18 \pm 0.03$ & $3.21 \pm 0.01$ & $2.85 \pm 0.02$ \\
\hline $850-600$ & $2.64 \pm 0.01$ & $2.53 \pm 0.03$ & $3.63 \pm 0.02$ & $3.22 \pm 0.02$ & $5.01 \pm 0.01$ & $3.95 \pm 0.01$ \\
\hline less than 600 & $3.59 \pm 0.01$ & $4.97 \pm 0.02$ & $7.02 \pm 0.01$ & $4.84 \pm 0.01$ & $7.17 \pm 0.01$ & $5.82 \pm 0.01$ \\
\hline Contact time $(\mathrm{min})$ & \multicolumn{2}{|c|}{30} & \multicolumn{3}{c|}{60} & \multicolumn{2}{c}{120} \\
\hline
\end{tabular}

It was observed that the adsorptive capacity of the two adsorbents studied increases the smaller the particle size. The reduction of the solid phase of particle size causes an increase in the contact surface between adsorbent and adsorbate, because of reduced resistance to mass transfer within the particles [52]. Thus, it adopted work with particle size less than $600 \mathrm{~mm}$. Moreover, it observed also that the dye adsorbed mass per gram of peat values were very similar for the different wavelengths studied. Thus, the subsequent results were presented on $612 \mathrm{~nm}$.

\subsection{Effect of Temperature}

Previous work [35] has shown the study about the adsorption of 5,5'-DI onto green coconut fiber (Cocos Nucifera L). Successive spectra (not presented here) of aliquots of the supernatant solutions obtained after the contact between FP and DP and $(2.00,2.99$ and 4.05$) \times 10^{-5} \mathrm{~mol} \mathrm{~L}^{-1}$ dye solution at different time-periods, at $(283,298,313) \mathrm{K}$, were registered. The increasing contact-time led to decreasing in the absorbances at $612 \mathrm{~nm}(\mathrm{pH} 2)$. This variation in the absorbance may be described to the adsorption of 5,5'-DI on the fibrous and decomposed peats surface causing the decrease in the concentration of 5,5'-DI in the supernatant solutions. The Fig. 4 show the mass-time profiles $\left(q_{t}=\right.$ $m_{5,5^{\prime} \text {-DI ads }} / m_{\text {peat }} v s \mathrm{t}$ ) for adsorption of dye on fibrous peat (FP) and decomposed peat (DP). The minimum absorbance (maximum sorption) was achieved before 1 hour at $(283,298,313) \mathrm{K}$ for two types of peat. The maximum sorption, $q_{\max }$, of 5,5'-DI per gram of FP is $7.17 \times 10^{-4}\left(\mathrm{~g} \mathrm{~g}^{-1}\right)$ and for DP is $5.82 \times 10^{-4}\left(\mathrm{~g} \mathrm{~g}^{-1}\right)$ at $298 \mathrm{~K}$, Table 5. The time profile of 5,5'-DI uptake is a single, smooth, and continuous curve leading to saturation, suggesting the possible monolayer coverage of 5,5'-DI on the surfaces of FP and DP adsorbents. In the same work [8], it was shown that the isotherm data could be well fitted by the Langmuir equation. It is well recognized that the characteristic of adsorbent surface is a critical factor that affects the sorption rate parameters and the film resistance plays an important role in the overall transport of the solute. The large number and array of different groups on fibrous peat (FP) and decomposed peat (DP) surfaces imply that there are different types of adsorbent-solute interactions. The increase in the adsorption capacity at a higher temperature indicated the endothermic 
nature of the adsorption process of 5, 5'-DI onto peat. Similar results of adsorption of dyes onto different adsorbents with a positive change in entropy and enthalpy have been reported in literature [53-56].
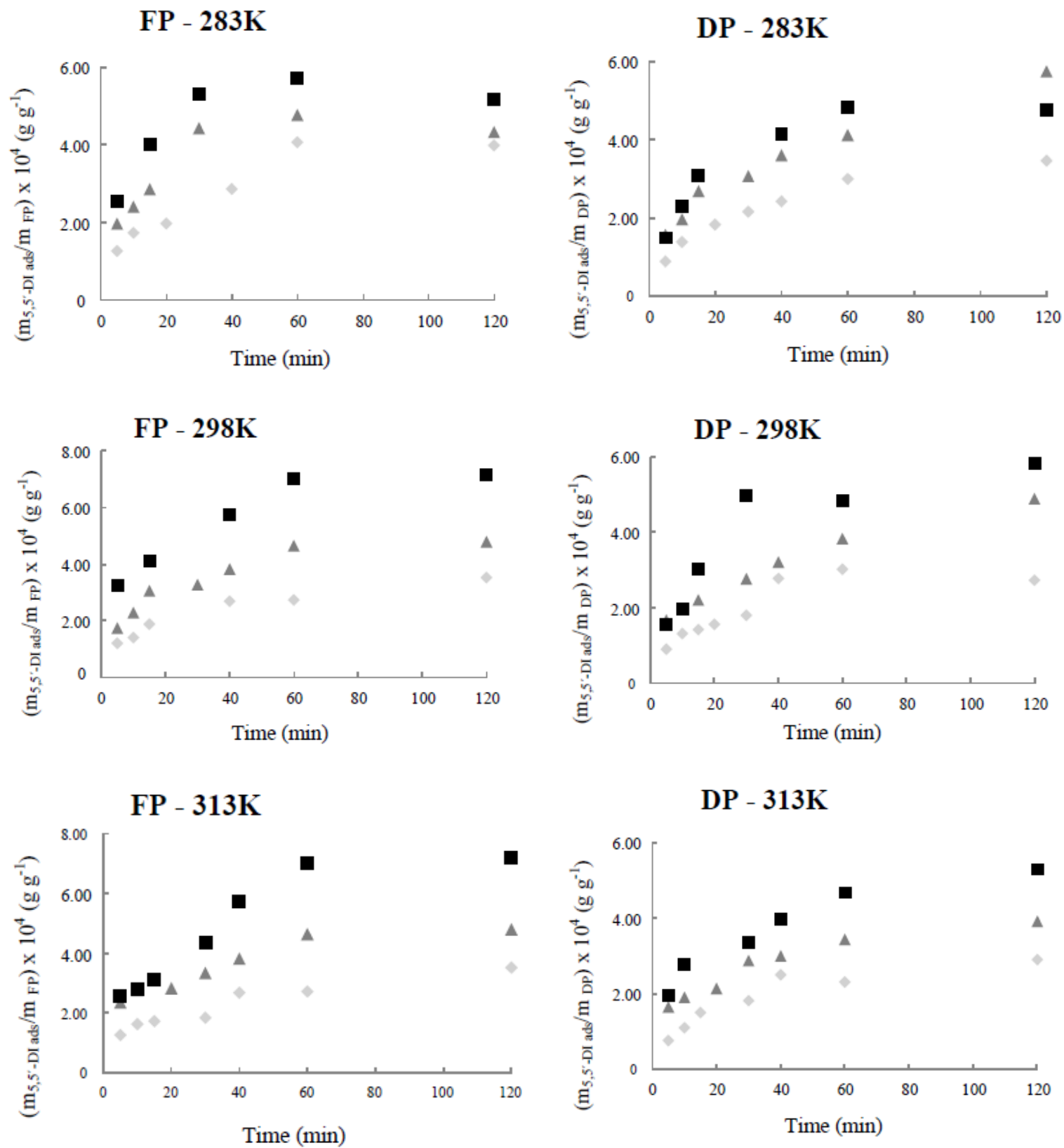

Figure4. Mass-time profiles $\left(q_{t}=m_{5,5^{\prime}-D I}\right.$ ads $/ m_{\text {peat }}$ vs $\left.t\right)$ for adsorption of dye on fibrous peat (FP) and decomposed peat $(D P)$ at $\left(283,298\right.$ e 313) K. [5, $\left.5^{\prime}-D I\right]$ initial $=(* 2.00,-2.99$ and 4.00$) \times 10^{-5} \mathrm{~mol} \mathrm{~L}^{-1}, 612$ nm.

Table5. Mass variation 5, 5'-DI adsorbed per gram of FP and DP as a function of contact time at different temperatures $\left(283,298\right.$ e 313) $\mathrm{K}, C_{o}=\left[5,5^{\prime}-\mathrm{DI}\right]$ initial $=\left(2.00,2.99\right.$ and 4.00) $\times 10^{-5} \mathrm{~mol} \mathrm{~L}^{-1}, 612 \mathrm{~nm}$.

\begin{tabular}{cccc}
\hline $\mathbf{C}_{\mathbf{0}}\left(\mathbf{m o l ~ L}^{-\mathbf{1}}\right)$ & $\mathbf{T}(\mathbf{K})$ & $\left(\boldsymbol{m}_{5,5^{\prime}-\mathbf{D I}} / \boldsymbol{m}_{\boldsymbol{F P}}\right) \times \mathbf{1 0}^{\mathbf{4}}\left(\mathbf{g ~ g}^{\mathbf{- 1}}\right)$ & $\left(\boldsymbol{m}_{5,5^{\prime}-\boldsymbol{D I}} / \boldsymbol{m}_{\boldsymbol{D P}}\right) \times \mathbf{1 0}^{\mathbf{4}}\left(\mathbf{g ~ g}^{\mathbf{- 1}}\right)$ \\
\hline \multirow{2}{*}{$2.00 \times 10^{-5}$} & 283 & $3.99 \pm 0.02$ & $3.45 \pm 0.04$ \\
& 298 & $3.54 \pm 0.01$ & $2.73 \pm 0.02$ \\
& 313 & $3.54 \pm 0.01$ & $2.88 \pm 0.03$ \\
\hline \multirow{2}{*}{$2.99 \times 10^{-5}$} & 283 & $4.34 \pm 0.01$ & $5.73 \pm 0.01$ \\
& 298 & $4.80 \pm 0.02$ & $4.88 \pm 0.01$ \\
& 313 & $4.81 \pm 0.03$ & $3.90 \pm 0.02$ \\
\hline \multirow{2}{*}{$4.00 \times 10^{-5}$} & 283 & $5.19 \pm 0.01$ & $4.74 \pm 0.01$ \\
& 298 & $7.17 \pm 0.01$ & $5.82 \pm 0.01$ \\
& 313 & $7.19 \pm 0.02$ & $5.27 \pm 0.01$ \\
\hline
\end{tabular}




\subsection{Adsorption Kinetics}

The kinetic adsorption study is essential to optimize the processes and ensure that significant adsorption of the 5,5'-DI occurred under different conditions. Furthermore, it is possible to determine the solute uptake rate that controls the residence time of the adsorbate at the solid-solution interface. Kinetic models were applied to interpret the experimental data in order to understand the mechanisms that control the adsorption process, such as the mass transfer in solution and the chemical interactions [8]. The first kinetic model used to fit the experimental data was that of Lagergren, eq.(3), which was the first equation developed to describe adsorption in liquid-solid systems based on the capacity of the solid [57,58]:

$$
\frac{d q_{t}}{d t}=k_{1}\left(q_{\text {max }, \text { calc }}-q_{t}\right)
$$

where $k_{l}\left(\mathrm{~min}^{-1}\right)$ is the rate constant of pseudo-first-order adsorption, $q_{\text {max }}$,alc is the maximum amount of 5,5'-DI adsorbed $\left(\mathrm{g}_{5,5^{\prime}-\mathrm{DI}} / \mathrm{g}_{\text {peat }}\right)$ (based on the adsorption capacity which corresponds to the monolayer coverage) and $q_{t}$ is the amount of 5,5'-DI adsorbed on the peat $\left(\mathrm{g}_{5.5^{\prime}-\mathrm{DI}} / \mathrm{g}_{\text {peat }}\right)$ when $t \neq 0$ and $t_{\max }$ (equilibrium time of solid-liquid system which corresponds to the maximum adsorption kinetics). Integrating eq.(3) considering the initial conditions as $q_{t}=0$ at $t=0$ and the equilibrium condition $q_{a d s}=q_{t}$ for each time $t$, becomes:

$$
\log \left(q_{\max }-q_{t}\right)=\log q_{\text {max }, \text { calc }}-\frac{k_{1}}{2,303} \times t
$$

By applying the pseudo-first order model to the experimental values (Figures are not shown here) the slope and the intercept of each linear fit were used to calculate the first order rate constant $\left(k_{l}\right)$ and the adsorption at equilibrium $\left(q_{\max , \text { calc }}\right)$. The correlation coefficients $\left(r^{2}\right)$ of the first order kinetic fit to the experimental conditions were not very good for all studied temperatures. Such behavior was observed throughout the contact time and initial concentration evaluated. Also, the values of $q_{\text {max,calc }}$ were quite different from the values found in the experimental kinetic study $\left(q_{\max , e x p}\right)$. These results suggest that the adsorption of 5,5'-DI onto peat does not follow a pseudo-first order model, indicating that 5,5'-DI does not adsorb onto material occupying one adsorption site. The adsorption kinetics may also be described by a pseudo-second order equation introduced by Blanchard et al. [59] and reviewed by Ho and McKay [42]:

$$
\frac{d q_{t}}{d t}=k_{2} \times\left(q_{\max , \text { calc }}-q_{t}\right)^{2}
$$

Table6. Pseudo-second order parameters for the adsorption of 5,5'-DI onto fibrous peat (FP) and decomposed peat (DP), $C_{o}$ (initial concentration), $k_{2}\left(\right.$ min $\left.^{-1} g_{F P} g^{-1} 5,5^{\prime}-D I\right)$ and $q_{\max , \text { calc }}\left(g_{5,5^{\prime}-D I} g^{-1} F_{F P}\right)$.

\begin{tabular}{cc|ccc|ccc}
\hline & & \multicolumn{3}{|c|}{ FIBROUS PEAT (FP) } & \multicolumn{3}{c}{ DECOMPOSED PEAT (DP) } \\
\hline $\begin{array}{c}\mathrm{C}_{\mathrm{o}} \\
\left(\mathrm{mol} \mathrm{L}^{-1}\right)\end{array}$ & $\mathrm{T}(\mathrm{K})$ & $k_{2} \times 10^{3}$ & $\begin{array}{c}q_{\text {max, calc }} \times \\
10^{4}\end{array}$ & $r^{2}$ & $k_{2} \times 10^{3}$ & $\begin{array}{c}q_{\text {max, calc }} \times \\
10^{4}\end{array}$ & $r^{2}$ \\
\hline \multirow{2}{*}{$2.00 \times$} & 283 & $0.18 \pm 0.01$ & $(4.50 \pm 0,01)$ & 0.9939 & $0.10 \pm 0,02$ & $4.11 \pm 0,01$ & 0.9908 \\
$10^{-5}$ & 298 & $0.16 \pm 0.01$ & $(3.90 \pm 0,02)$ & 0.9871 & $0.20 \pm 0,01$ & $3.07 \pm 0,02$ & 0.9933 \\
& 313 & $0.16 \pm 0.02$ & $(3.86 \pm 0,01)$ & 0.9848 & $0.14 \pm 0,01$ & $3.38 \pm 0,01$ & 0.9927 \\
\hline \multirow{2}{*}{$2.99 \times$} & 283 & $0.24 \pm 0.01$ & $(4.66 \pm 0,01)$ & 0.9985 & $0.05 \pm 0,02$ & $6.81 \pm 0,05$ & 0.9910 \\
$10^{-5}$ & 298 & $0.16 \pm 0.01$ & $(5.24 \pm 0,02)$ & 0.9984 & $0.09 \pm 0,03$ & $5.48 \pm 0,03$ & 0.9777 \\
& 313 & $0.16 \pm 0.02$ & $(5.44 \pm 0,03)$ & 0.9901 & $0.21 \pm 0,01$ & $4.18 \pm 0,01$ & 0.9933 \\
\hline \multirow{2}{*}{$4.00 \times$} & 283 & $0.36 \pm 0.01$ & $(5.57 \pm 0,01)$ & 0.9901 & $0.17 \pm 0,01$ & $5.29 \pm 0,01$ & 0.9957 \\
$10^{-5}$ & 298 & $0.11 \pm 0.01$ & $(7.92 \pm 0,02)$ & 0.9932 & $0.07 \pm 0,01$ & $6.74 \pm 0,01$ & 0.9950 \\
& 313 & $0.07 \pm 0.03$ & $(8.29 \pm 0,02)$ & 0.9845 & $0.12 \pm 0,02$ & $5.83 \pm 0,01$ & 0.9920 \\
\hline
\end{tabular}

Where $k_{2}$ is the pseudo-second order adsorption rate constant, $\left(\mathrm{min}^{-1} \mathrm{~g}_{\text {peat }} / \mathrm{g}_{5,5^{\prime}-\mathrm{DI}}\right)$, and $q_{\text {max,calc }}$ and $q_{t}$ have the same definitions as in eq.(4). Integrating eq. (5) and applying the same boundary conditions gives we can obtain:

$\frac{t}{q_{t}}=\frac{1}{k_{2} q_{\max , \text { calc }}^{2}}+\frac{1}{q_{\max , \text { calc }}} t$ 
The second-order rate constant $\left(k_{2}\right)$ and the maximum amount of 5, 5'-DI adsorbed $\left(q_{\max , \text { calc }}\right)$ may be calculated from the intercept and the slope of the linear relationship, eq.(6), between $t / q_{t}$ and $t$. The curve fit was calculated by adjusting eq. (6) to the experimental data (Figures are not shown here). The parameters $q_{\text {max, } \text { calc }}$ and $k_{2}$ are shown in Table 6.

The correlation coefficients $\left(r^{2}\right)$ for the pseudo-second order kinetic model fit are very good and the values of $q_{\max , \text { calc }}$ (Table 6) are quite similar to those obtained from the kinetic experiment data $\left(q_{\max , \text { exp }}\right)$ at different temperatures $(283,298$ and 313) $\mathrm{K}$ and initial concentrations of 5,5'-DI (2.00, 2.99 and 4.00$) \times 10^{-5} \mathrm{~mol} \mathrm{~L}^{-1}$, both for fibrous and decomposed peats. At $283 \mathrm{~K}, 298 \mathrm{~K}$ and $313 \mathrm{~K}$, for FP the maximum sorption, $q_{\text {max,exp }}$, for the lowest initial concentration $\left(\mathrm{C}_{\mathrm{o}}=2.00 \times 10^{-5} \mathrm{~mol} \mathrm{~L}^{-1}\right)$ of 5.5 -DI were $\left(4.50,3.90\right.$ and 3.86) $\times 10^{-4} \mathrm{~g} \mathrm{~g}^{-1}$; for $\mathrm{C}_{\mathrm{o}}=2.99 \times 10^{-5} \mathrm{~mol} \mathrm{~L}^{-1}\left(4.66,5.24\right.$ and 5.44) $\times 10^{-}$ ${ }^{4} \mathrm{~g} \mathrm{~g}^{-1}$ and for $\mathrm{C}_{\mathrm{o}}=4.00 \times 10^{-5} \mathrm{~mol} \mathrm{~L}^{-1}\left(5.57,7.92\right.$ and 8.29) $\times 10^{-4} \mathrm{~g} \mathrm{~g}^{-1}$, respectively. And for decomposed peat (DP) the maximum sorption, $q_{\max , \text { exp }}$, for the lowest initial concentration $\left(\mathrm{C}_{\mathrm{o}}=2.00 \times\right.$ $\left.10^{-5} \mathrm{~mol} \mathrm{~L}^{-1}\right)$ of 5.5-DI were $\left(4.11,3.07\right.$ and 3.38) $\times 10^{-4} \mathrm{~g} \mathrm{~g}^{-1}$; for $\mathrm{C}_{\mathrm{o}}=2.99 \times 10^{-5} \mathrm{~mol} \mathrm{~L}^{-1}(6.81,5.48$ and 4.18) $\times 10^{-4} \mathrm{~g} \mathrm{~g}^{-1}$ and for $\mathrm{C}_{\mathrm{o}}=4.00 \times 10^{-5} \mathrm{~mol} \mathrm{~L}^{-1}(5.29,6.74$ and 5.83$) \times 10^{-4} \mathrm{~g} \mathrm{~g}^{-1}$ at $283 \mathrm{~K}, 298 \mathrm{~K}$ and $313 \mathrm{~K}$, respectively. The pseudo-second order model fit suggests that the interaction of each molecule of dye with the fiber surface occurs by the occupation of two sites on the biomaterial, as a hypothetical model presented in the Fig. 5.

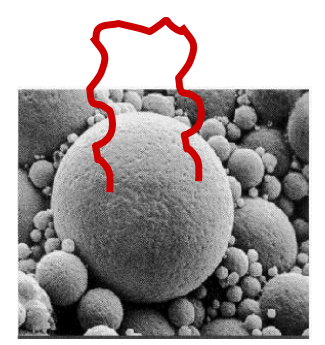

Figure5. A hypothetical representation of occupation of the active sites in pseudo-second order model

In the lowest initial concentration $\left(\mathrm{C}_{\mathrm{o}}=2.99 \times 10^{-5} \mathrm{~mol} \mathrm{~L}^{-1}\right)$, the large number of adsorption sites favored the adsorption and, consequently, $k_{2}$ presents a higher value for all temperatures studied 283 $\mathrm{K}\left(0.05 \times 10^{3} \mathrm{~min}^{-1}\right), 298 \mathrm{~K}\left(0.09 \times 10^{3} \mathrm{~min}^{-1}\right)$ and $\left(0.21 \times 10^{3} \mathrm{~min}^{-1}\right)$. However, considering all 5, $5^{\prime}-$ DI initial concentrations, values of $k_{2}$ show an irregular variation. A minimum value was observed and as a result, $k_{2}$ tends to a constant value, irrespective of the initial concentration. Therefore, considering the whole time interval and 5,5'-DI concentrations, it can be assumed that the adsorption mechanism follows the pseudo-second order model. It was observed that the increase in values of the maximum amount of 5,5'-DI adsorbed, $q_{\text {max,calc }}$, for $\mathrm{C}_{\mathrm{o}}=(2.00,2.99$ and 4.00$) \times 10^{-5} \mathrm{~mol} \mathrm{~L}^{-1}$ respectively with an increase in the temperature $283 \mathrm{~K}, 298 \mathrm{~K}$ and $313 \mathrm{~K}$ indicates a possible endothermic system. Similar behavior was seen in literature [53-56].

Adsorption involves varied stages, where the rate-controlling step is the intraparticle diffusion mechanism. Close to the equilibrium, the intraparticle diffusion becomes slower due to low concentration. Considering that pseudo-first order and -second models cannot identify the diffusion mechanisms, an intraparticle diffusion model [60] was also evaluated. The rate parameters for intraparticle diffusion $\left(k_{P}\right)$ may be obtained by using eq. (7), where $q_{t}$ is the amount of 5,5'-DI on peat at different times, $\mathrm{t}(\mathrm{min})$ :

$q_{t}=k_{P} t^{1 / 2}+B$

$k_{P}$ is the intraparticle diffusion rate constant $\left(\min ^{-1 / 2} \mathrm{~g}_{5,5^{\prime} \text {-DI }} / \mathrm{g}_{\text {peat }}\right.$ ). According to eq. $(7)$, a plot of $q_{t}$ versus $t^{1 / 2}$ should be a straight line with a slope corresponding to $k_{P}$ when the intraparticle diffusion is a rate-limiting step and $B$ is the intercept corresponding to the linear coefficient. The intraparticle diffusion model could be applied to experimental data obtained in different initial concentrations for FP and DP (Table 7). It was observed that nonlinear plots over the whole range of time (multilinearity) indicating that other processes drive the adsorption of 5,5'-DI on each peat. In general, a first sharper portion of the curve may be considered as an external surface adsorption or a faster adsorption stage. A second portion is a gradual adsorption stage, where intraparticle diffusion is rate-controlled and an irregular variation of the diffusion rate with the initial 5,5'-DI concentration was observed. The third portion is attributed to the final equilibrium stage where the intraparticle diffusion is slower due to the extremely low adsorbate concentrations in solution [35]. A hypothetical representation of occupancy of sites in the intraparticle diffusion model is shown in Fig. 6. 


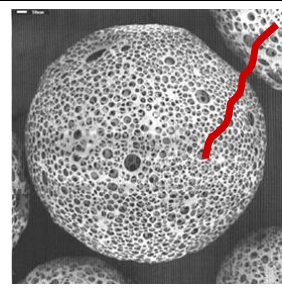

Figure6. A hypothetical representation of occupation of the active sites an intraparticle diffusion model.

The rate of uptake might be limited by size of adsorbate molecule, concentration of the adsorbate and its affinity to the adsorbent, diffusion coefficient of the adsorbate in the bulk phase, the pore-size distribution of the adsorbent and agitation rate. Values of $k_{P}\left(\mathrm{~min}^{-1 / 2} \mathrm{~g}_{5,5^{\prime} \text {-DI }} / \mathrm{g}_{\text {peat }}\right)$ and the correlation coefficients for all 5,5'-DI initial concentrations investigated are shown in Table 7. High correlation coefficient $(r>0.97)$ is found to the range of the experimental data to the diffusion model. The second portion of the curves can be attributed to intraparticle diffusion [45] and an irregular variation of the diffusion rate with initial 5,5'-DI concentration and temperature were observed.

Table7. Intraparticle diffusion parameters for the adsorption of 5,5'-DI onto fibrous peat (FP) and decomposed peat (DP), $C_{o}$ (initial concentration), $k_{P}\left(\mathrm{~min}^{-1 / 2} g_{5,5^{\prime}-D I} g_{F P}^{-1}\right)$.

\begin{tabular}{cc|cc|cc}
\hline & & \multicolumn{2}{|c|}{ FIBROUS PEAT (FP) } & \multicolumn{2}{c}{ DECOMPOSED PEAT (DP) } \\
\hline $\begin{array}{c}\mathrm{C}_{\mathrm{o}} \\
\left(\mathrm{mol} \mathrm{L}^{-1}\right)\end{array}$ & $\mathrm{T}(\mathrm{K})$ & $k_{P} \times 10^{5}$ & $r^{2}$ & $k_{P} \times 10^{5}$ & $r^{2}$ \\
\hline \multirow{2}{*}{$2.00 \times 10^{-5}$} & 283 & $3.02 \pm 0.02$ & 0.9829 & $2.90 \pm 0.03$ & 0.9683 \\
& 298 & $2.72 \pm 0.01$ & 0.9982 & $1.97 \pm 0.02$ & 0.9750 \\
& 313 & $2.53 \pm 0.01$ & 0.9976 & $2.43 \pm 0.01$ & 0.9824 \\
\hline \multirow{2}{*}{$2.99 \times 10^{-5}$} & 283 & $2.96 \pm 0.01$ & 0.9909 & $2.67 \pm 0.01$ & 0.9902 \\
& 298 & $4.18 \pm 0.02$ & 0.9886 & $4.78 \pm 0.01$ & 0.9965 \\
$4.00 \times 10^{-5}$ & 313 & $5.76 \pm 0.03$ & 0.9863 & $5.75 \pm 0.03$ & 0.9463 \\
\hline & 283 & $3.01 \pm 0.01$ & 0.9957 & $3.78 \pm 0.02$ & 0.9704 \\
& 298 & $4.79 \pm 0.04$ & 0.9475 & $4.92 \pm 0.05$ & 0.9371 \\
\hline
\end{tabular}

An irregularity of the $k_{P}$ values was also reported in literature [35] that can be related to either the heterogeneity of the material or the capability of adsorbate molecules to agglomerate on its surface. Intercept values of the linear diffusion segments, named as $B$, does not pass through the origin of the graphic plot indicating that intraparticle diffusion is not the single mechanism rate-controlling and other mechanisms may control the rate adsorption. Validation requires the comparison of quantitative correlation coefficients, and they can be seen in the graphs of the linear equation used in its respective kinetic model [33]. Fibrous peat (FP) and decomposed peat (DP) has a high level of compression where most of the binding sites are not exposed to the substrate. However, certain solvents can swell (decompressing) the peat, exposing more ligands within the cellulosic network for binding with the adsorbate [35]. For all temperatures it was observed that as the initial concentration increased (2.00, 2.99 and 4.00) $\times 10^{-5} \mathrm{~mol} \mathrm{~L}^{-1}$ the intraparticle diffusion constant increase too (Table 7).

\section{Conclusions}

Peat showed considerable potential low cost adsorbent for its use in the adsorption of 5,5'-DI from aqueous solution. The fibrous peat shows higher adsorption capacity than the decomposed peat, while under the same work conditions. The adsorbent had good adsorption capacity for 5,5'-DI and showed strong adsorption as the initial concentration of the 5,5'-DI was increased. The kinetic study demonstrated that the equilibrium time of contact was about 60 minutes for both temperatures and dye initial concentration. The pseudo-second order adsorption model adequately represents the interaction of 5,5'-DI with FP and DP, showing that adsorption occurs by the occupation of two active sites on the surface of the bio(adsorbent) as reported in literature [53-56]. Considering adsorption, desorption, kinetic modeling and physical properties of the adsorbent, peat is an appropriate material in future analytical applications.

\section{ACKNOWLEDGEMENTS}

FAPESP, CNPq, UFABC and CEUN-IMT, Professor Dra. Maria Encarnácion Vázquez Suárez Iha (Mackenzie), Professor Ivanise Gauber (UFABC) 


\section{REFERENCES}

[1] R. M. Dallago, A. Smaniotto, L. C. A de Oliveira, Solid waste from tanneries as adsorbent for the removal of dyes in aqueous medium, Química Nova, vol. 28, pp. 433-437, 2005.

[2] S. Torres, S. Cerutti, J. Raba, P. Pacheco, M. F. Silva, Preconcentration of seleno-amino acids on a XAD resin and determination in regional olive oils by SPE UPLC-ESI-MS/MS, Food Chemistry, vol. 159(15), pp. 407-413, 2014.

[3] T. Tuzimski, T. Rejczak, Application of HPLC-DAD after SPE/QuEChERS with $\mathrm{ZrO}_{2}$-based sorbent in d-SPE clean-up step for pesticide analysis in edible oils, Food Chemistry, vol. 190(1), pp. 71-79, 2016.

[4] R. Yang, W. Hu, L. Xu, Y. Song, J. Li, Synthesis, mechanical properties and fire behaviors of rigid polyurethane foam with a reactive flame retardant containing phosphazene and phosphate, Polymer Degradation and Stability, vol. 122, pp. 102-109, 2015.

[5] P. A. de M. Freitas, K. Iha, M. C. F. C. Felinto, M. E. V. Suárez-Iha, Adsorption of di-2-pyridyl ketone salicyloylhydrazone (DPKSH) on Amberlite XAD-2 and XAD-7 resins: characteristics and isotherms, Journal of Colloid and Interface Science, vol. 323(1), pp.1-5, 2008.

[6] A. S. Amin, I. A. Zaafarany, Spectrophotometric determination of bismuth after solid-phase extraction using amberlite XAD-2 resin modified with 5-(2'-bromophenylazo)-6-hydroxy pyrimidine-2,4-dione, Journal of Taibah University for Science, vol. 9(4), pp. 490-497, 2015.

[7] A. Ahmad, J. A. Siddique, M. A. Laskar, R. Kumar, S. H. Mohd-Setapar, A. Khatoon, R. A. Shiekh, New generation Amberlite XAD resin for the removal of metal ions: A review, Journal of Environmental Sciences, vol. 31(1), pp. 104-123, 2015.

[8] P. Antonio, K. Iha, M. E. V. Suárez-Iha, Adsorption of di-2-pyridyl ketone salicyloylhydrazone on silica gel: characteristics and isotherms, Talanta, vol. 64, pp. 484-490, 2004.

[9] P. Antonio, Adsorção de di-2-piridil cetona saliciloilhidrazona em silica-gel. São Paulo. Dissertação de Mestrado, IQ-USP, pp. 1-51, 2003.

[10] P. Antonio, K. IHA, M. E. V. Suárez-Iha, Kinetic modeling of adsorption of di-2-pyridylketone salicyloylhydrazone on silica gel, Journal of Colloid and Interface Science, vol. 307, p. 24-28, 2007.

[11] L. Wang, Z. Nie, C. Cao, S. Khalid, Y. W., X. Xu, Carbon-wrapped $\mathrm{TiO}_{2}$ nanocubes exposed with (001) active facets for high-rate and long-life lithium-ion batteries, Journal of Power Sources, vol. 302, pp. 259-265, 2016.

[12] F. Ma, C. Peng, D. Hou, B. Wu, Q. Zhang, F. Li, Q. Gu, Citric acid facilitated thermal treatment: An innovative method for the remediation of mercury contaminated soil, Journal of Hazardous Materials, vol. 300(30), pp. 546-552, 2015.

[13] Y. Yamazaki, Y. Tachibana, T. Kaneshiki, M. Nomura, T. Suzuki, Adsorption behavior of uranium ion using novel phenol-type resins in contaminated water containing sea water, Progress in Nuclear Energy, vol. 82, pp. 74-79, 2015.

[14] L. Shu-Ting, Y. Kang-kang, Z. Yuan-hu, J. Shi-di, Y. Ying, C. Xue-Gang, Magnesiothermic reduction of rice husk ash for electromagnetic wave adsorption, Journal of Magnetism and Magnetic Materials, vol. 394, pp. 266-273, 2015.

[15] J. M. Prado, T. Forster-Carneiro, M. A. Rostagno, L. A. Follegatti-Romero, F. Maugeri Filho, M. A. A. Meireles, Obtaining sugars from coconut husk, defatted grape seed, and pressed palm fiber by hydrolysis with subcritical water, The Journal of Supercritical Fluids, vol. 89, pp. 89-98, 2014.

[16] D. Lachos-Perez, F. Martinez-Jimenez, C.A. Rezende, G. Tompsett, M. Timko, T. ForsterCarneiro, Subcritical water hydrolysis of sugarcane bagasse: An approach on solid residues characterization, The Journal of Supercritical Fluids, vol. 108, pp. 69-78, 2016.

[17] W. Nitayaphat, T. Jintakosol, Removal of silver(I) from aqueous solutions by chitosan/bambo charcoal composite beads, Journal of Cleaner Production, vol. 87, pp. 850-855, 2015.

[18] L. Li, M. Gao, J. Liu, X. Guo, Removal of airborne microorganisms emitted from a wastewater treatment oxidation ditch by adsorption on activated carbon, Journal of Environmental Sciences, vol. 23(5), pp. 711-717, 2011. 
[19] S. C. Aguiar, Fontes energéticas brasileiras - inventário/tecnologia: Turfa, CHESF, vol. I e II, Rio de Janeiro, 1987.

[20] T. Gosset, J. L. Trancart, D. R. Thevenot, Batch Metal Removal by Peat - I. Kinetics and Thermodynamics, Wat. Res., vol. 20, pp. 21-26, 1986.

[21] Y. S. Ho, G. Mckay, Sorption of dye from aqueous solution by peat, Chem. Eng. Journal, vol. 70, pp. 115-124, 1998.

[22] Y. S. Ho, G. Mckay, The sorption of lead(11) ions on peat, Water. Resarch, vol. 33(2), pp. 578584, 1999.

[23] O. Callery, R. B. Brennan, M.G. Healy, Use of amendments in a peat soil to reduce phosphorus losses from forestry operations, Ecological Engineering, vol. 85, pp. 193-200, 2015.

[24] B. Dousova, F. Buzek, J. Rothwell, S. Krejcova, M. Lhotka, Adsorption behavior of arsenic relating to different natural solids: Soils, stream sediments and peats, Science of The Total Environment, vol. 433, pp. 456-461, 2012.

[25] A. N. Fernandes, C. A. P. Almeida, N. A. Debacher, M. M. de S. Sierra, Isotherm and thermodynamic data of adsorption of methylene blue from aqueous solution onto peat, Journal of Molecular Structure, vol. 982(1-3), pp. 62-65, 2010.

[26] B. Sen Gupta, M. Curran, S. Hasan, T. K. Ghosh, Adsorption characteristics of $\mathrm{Cu}$ and Ni on Irish peat moss, Journal of Environmental Management, vol. 90(2), pp. 954-960, 2009.

[27] Y. Kalmykova, A. M. Strömvall, B. M. Steenari, Adsorption of $\mathrm{Cd}, \mathrm{Cu}, \mathrm{Ni}, \mathrm{Pb}$ and $\mathrm{Zn}$ on Sphagnum peat from solutions with low metal concentrations, Journal of Hazardous Materials, vol. 152(2), pp. 885-891, 2008.

[28] W. Gao, J. Liang, L. Pizzul, X. M. Feng, K. Zhang, M. del P. Castillo, Evaluation of spent mushroom substrate as substitute of peat in Chinese biobeds, International Biodeterioration \& Biodegradation, vol. 98, pp. 107-112, 2015.

[29] F. Gallart, N. Clotet-Perarnau, O. Bianciotto, J. Puigdefàbregas, Peat soil flows in Bahía del Buen Suceso, Tierra del Fuego (Argentina), Geomorphology, vol. 9(3), pp. 235-241, 1994.

[30] E. I. Ekwue, D. Seepersad, Effect of soil type, peat, and compaction effort on soil strength and splash detachment rates, Biosystems Engineering, vol. 136, pp. 140-148, 2015.

[31] J. M. Márquez-Reyes, U. J. López-Chuken, A. Valdez-González, H. A. Luna-Olvera, Removal of chromium and lead by a sulfate-reducing consortium using peat moss as carbon source, Bioresource Technology, vol. 144, pp. 128-134, 2013.

[32] M. J. Nalbandian, M. Zhang, J. Sanchez, Y. Choa, J. Nam, D. M. Cwiertny, N. V. Myung, Synthesis and optimization of $\mathrm{Fe}_{2} \mathrm{O}_{3}$ nanofibers for chromate adsorption from contaminated water sources, Chemosphere, vol. 144, pp. 975-981, 2016.

[33] A. León-Torres, E. M. Cuerda-Correa, C. Fernández-González, M. F. A. Franco, V. GómezSerrano, On the use of a natural peat for the removal of $\mathrm{Cr}(\mathrm{VI})$ from aqueous solutions, Journal of Colloid and Interface Science, vol. 386(1), pp. 325-332, 2012.

[34] B. Dousova, F. Buzek, J. Rothwell, S. Krejcova, M. Lhotka, Adsorption behavior of arsenic relating to different natural solids: Soils, stream sediments and peats, Science of The Total Environment, vol. 433(1), pp. 456-461, 2012.

[35] L. F. Zeferino, I. Gaubeur, M. E. V. Suárez-Ilha, P. A. M. Freitas, Adsorption of 5,5'disulfonicindigotin (5,5'-DI) onto green coconut fiber (Cocos nucifera L.): Kinetic and Isotherms, Journal of Encapsulation and Adsorption Sciences, vol. 4, pp. 37-52, 2014.

[36] K. O. Chaves, C. R. L. Monteiro, C. R. Muniz, R. B. Gomes, H. L. B. Buarque, Adsorção de indigo carmim em biomassas mortas de aspergillus niger, Engenharia Sanitária e Ambiental, vol. 13, pp. 351-355, 2008.

[37] M. Sequin-Frey, The Chemistry of Plant and Animal Dyes, J. Chem. Education, vol. 58(4), pp. 301-307, 1981.

[38] [38] A. Bayer, V. Drewson, Darstellung von Indigblauaus Orthonitrobenzaldehyd, Berichte der Deutschen Chemischen Gesellschaft, vol. 15, pp. 2856-2864, 1982.

[39] From wastewater through adsorption, Journal of Hazardous Materials, vol. 137, pp. 591-602, 2006. 
[40] C. L. Jenkins, Textile dyes are potential hazards, Journal of environmental health, vol. 40, pp. 7$12,1978$.

[41] E. Oguz, Thermodynamic and kinetic investigations of $\mathrm{PO}_{4}{ }^{3-}$ adsorption on blast furnace slag, Journal Colloid and Interface Science, vol. 281, pp. 62-67, 2005.

[42] Y. S. Ho, G. McKay, Pseudo-second order model for sorption processes, Proc. Biochem., vol. 34, pp. 451-465, 1999.

[43] W. J. Weber Jr., J. C. Morris, J. Sanit, Kinetics of adsorption on carbon from solution Eng. Div. Proceed, Am. Soc. Civil Eng., vol. 89, pp. 31-38, 1963.

[44] M. S. Bilgili, Adsorption of 4-chlorophenol from aqueous solutions by XAD-4 resin: Isotherm, kinetic and thermodynamic analysis, J. Hazard. Mat., vol. B137, pp. 157-164, 2006.

[45] R. Katal, M. S. Baei, H. T. Rahmati, H. Esfadian, Kinetic isotherm and thermodynamic study of nitrate adsorption from aqueous solution using modifies rice husk, Journal Industrial and Eng. Chem., vol. 18, pp. 295-302, 2012.

[46] J. G. Huddleston, H. D. Willauer, K. R. Boaz, R. D. Roger, Separation and recovery of food coloring dyes using aqueous biphasic extraction chromatographic resins, Journal of Chromatography, vol. 711, pp. 237-244, 1998.

[47] N. Barka, A. Assabbane, A. Nounah, Y. A. Ichou, Photocatalytic degradation of indigo carmine in aqueous solution by $\mathrm{TiO}_{2}$-coated non-woven fibres, Journal of Hazardous Materials, vol. 152, pp. 1054-1059, 2008.

[48] J. J. Berzas, J. R. Flores, M. J. V. Llerena, N. R. Farinas, Spectrophotometric resolution of ternary mixtures of Tartrazine, Patent Blue V and Indigo Carmine in commercial products, Analytica Chimica Acta, vol. 391, pp. 353-364, 1999.

[49] H. L. Zheng, W. Q. Xiong, Y. K. Gong, D. J. Peng, L. C. Li, Catalytic spectrophotometric determination of trace aluminum with indigo carmine, Spectrochimica Acta Part A, vol. 66, pp. 1243-1247, 2007.

[50] D. W. Boykin, A Convenient Apparatus for small-scale dyeing with indigo, Journal of Chemical Education, vol. 75, pp. 769-770, 1998.

[51] N. Meksi, M. Kechida, F. Mhenni, Cotton dyeing by indigo with borohydride process: Effect of some experimental conditions on indigo reduction and dyeing quality, Chemical Engineering Journal, vol. 131, pp. 187-193, 2007.

[52] A. V. T. Piza, Avaliação da capacidade adsortiva de carvões ativados para a remoção de diuron e hexazinona, Tese de Mestrado, vol. 1, UNAERP, 2008.

[53] Q. Q. Zhong, Q. Y. Yue, Q. Li, X. Xu, B. Y. Gao, Preparation, characterization of modified wheat residue and its utilization for the anionic dye removal, Desalination, vol. 267, pp. 193-200, 2011.

[54] C. Y. Kuo, C. H. Wu, J. Y. Wu, Adsorption of reactive dyes on titania-silica mesoporous materials. J. Colloid and Interface Science, 299, 305-320.

[55] G. L. Dotto, M. L. G. Vieira, J. O. Gonçalves, L. A. A. Pinto, Remoção dos corantes azul brilhante, amarelo crepúsculo e amarelo tartrazina de soluções aquosas utilizando carvão ativado, terra ativada, terra diatomácea, quitina e quitosana: estudos de equilíbrio e termodinâmica, Química Nova, vol. 34(7), pp. 1193-1199, 2011.

[56] W. Q. Cai, J. G. Yu, B. Cheng, B. L. Su, M. Janoriec, Synthesis of boehmite hollow core/shell and hollow microspheres via sodium tartrate-mediated phase transformation and their enhanced adsorption performance in water treatment, J. Phys. Chem. C., vol. 113(33), pp. 14739-14746, 2009.

[57] S. Langergren, Zurtheorie der sogenannten adsorption geloesterstoffe, VeternskapsakadHandlingar, vol. 24, pp.1-9, 1898.

[58] J. Yener, T. Kopac, G. Dogu, T. Dogu, Adsorption of basic yellow 28 from aqueous solutions with clinoptilolite and amberlite, J. Colloid and Interface Science, vol. 294, pp. 255-264, 2006.

[59] Blanchard, G., Maunaye, M., Martim, G., Removal of heavy metals from waters by means of natural zeolites, Water Research, vol. 18, pp.1501-1507, 1984.

[60] G. Annadurai, R. S. Juang, D. J. Lee, Use of cellulose-base wastes for adsorption of dyes from aqueous solutions. J. Hazard. Mat., vol. B92, pp. 263-274, 2002. 


\section{AUTHORS' BIOGRAPHY}

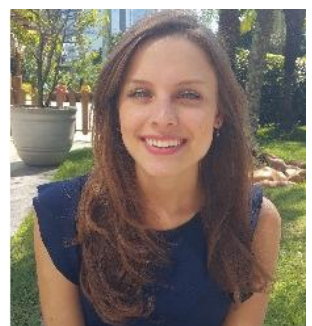

Maria Fernanda, is a final year student of Chemical Engineering at CEUNIMT and studied abroad at UWA for one year. Her technical background includes research in adsorption and drying at CEUN-IMT and in nano heat transfer at Australian Resources Research Centre. She tutored Mass and Energy Balances and Computer Analysis and Visualization. Moreover, she had experience as a Quality Management Director at Mauá Jr. and volunteered for Engineers without Borders.

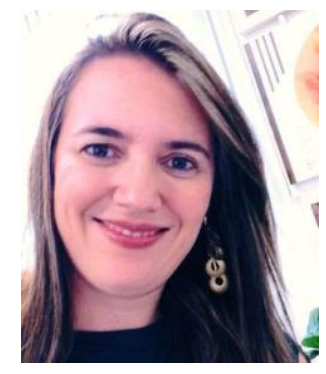

Patricia Antonio de Menezes Freitas, Degree in Chemical Engineering from School of Engineering Mauá, CEUN-IMT (1996), Master in Chemistry, Analytical Chemistry concentration area, the University of São Paulo (2003), $\mathrm{PhD}$ in Chemistry, Analytical Chemistry concentration area, the University of São Paulo (2007) and Postdoctoral Fellow in Chemical technology from Federal University of ABC (UFABC) in 2012. I'm a Professor of School of Engineering Mauá in the fields of Chemical Engineering and Food Engineering. I have experience in the development of analytical methods in the adsorption area, preconcentration and speciation of metal ions in different samples. It was coordinator of FAPESP 2010/18713-5 and 2011/21511-8 project that studied the removal of Indigo Blue dye, dye in textile industry, wastewater using coconut fiber as bioadsorbent. Nowadays I'm studying the modification of different adsorbents (coconut fiber, XAD resins, peat, silica gel, IRA-400, zeolites) with hydrazones, dyes and metal ions. In addition, I work in the development of cosmetic formulations and personal care products in laboratory and pilot scales. I'm guiding students to develop projects in the field of science and technology, in partnership with Professor. Dra. Ivanise Gaubeur the Federal University of ABC. It is the general coordinator of the Engineering Week Mauá since 1999 to date. In 2013 I received a AEXAN Featured EUREKA 2013 award from the guidance of best graduate work entitled cardboard production and paper with green coconut shell in the category Chemical Engineering. I had been received the title of Professor ABEQ (Brazilian Association of Chemical Engineering) in 2015 representing de School of Engineering Mauá. 